\title{
BRITISH FOLLICULINIDAE (CILIATA, HETEROTRICHA)
}

\author{
By S. M. Das, D.Sc., F.Z.S. \\ From the Plymouth Laboratory and Cullercoats Marine Laboratory, England*
}

\section{(Text-figures I-3)}

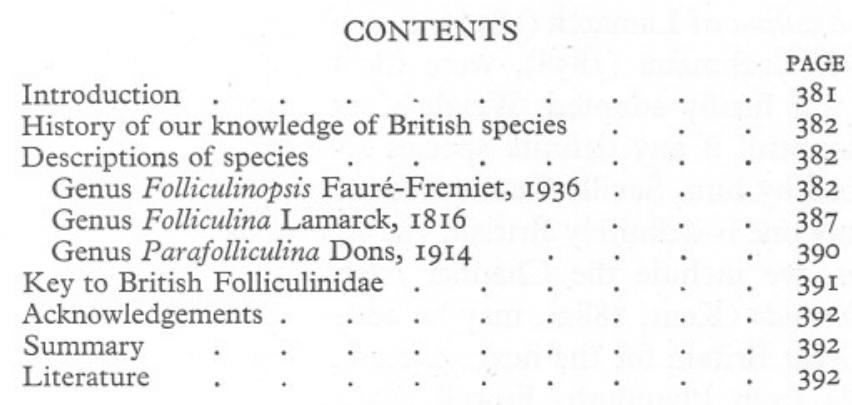

\section{INTRODUCTION}

The Folliculinidae are a well-marked family of heterotrichan ciliates, most of which are marine and have a world-wide distribution. They are abundant in most marine aquaria, while in the sea they are usually found attached to Algae, Polyzoa, Crustacea, Mollusca, tube-building Annelida or tests of Tunicata, down to a depth of about 5 fathoms. The family is characterized by: (a) the blue or bottle-green colour of the body; (b) the large bilobed peristomial field; (c) secretion of a case in the form of a bottle or flask; $(d)$ the two phases in its life, one sedentary and the other migratory; and (e) dedifferentiation of the adult to form the migratory phase and its reorganization into the sedentary phase.

Since the latest publication on British Folliculinidae (Das, 1947b), the present author had the opportunity of examining six species of Folliculinidae during his stay in Great Britain. If the records by other workers of Folliculinopsis ampulla (Müller) be correct, and if Parafolliculina hirundo (Kent) be included, we now have eight definite species of British folliculinids; whereas until 1946 only three species were known. An attempt has been made in this paper to give complete, and for most revised, descriptions of these eight species. The classification followed here is after Fauré-Fremiet (1936b), who has shown that many of the genera listed by $\operatorname{Kahl}($ I932, I933) are not based on well-marked anatomical characters but on the case or lorica alone. Besides, many of the original descriptions by Kent (I88I-82) require revision on the basis of work done since then. The characters used for differentiation of species

* Present address: Central Marine Fisheries Station, West Hill, S. India. 
are: (i) the size and shape of the case and the body; (ii) the nature of the macronucleus; (iii) the structure of the cell-body; (iv) the colour and nature of pigment; (v) the ciliary bands; (vi) the peristomial lobes; and (vii) the shape and structure of the larva along with the nature of metamorphosis.

\section{History OF OUR KNOWLEDGe OF BRITISH SPECIES}

Our knowledge of British Folliculinidae dates back to I880, when Wright (I858-9, I862) described a species as Lagotia viridis. Stein (I867) showed that the Folliculina of Lamarck (I8I6), Lagotia of Wright (I858), and Freia of Claparède \& Lachmann (I858), were identical; and thus the prior name Folliculina was finally adopted. Wright's species were mostly from Ireland, and it is doubtful if any definite species from England, Scotland or Wales was described by him. Saville Kent (I88I-82, pp. 596-60I) listed six species, of which only one is definitely British, viz. F. ampulla Müller from Falmouth. If, however, we include the Channel Islands then another species, Parafolliculina hirundo (Kent, I882), may be added. Little work was done on the family in Great Britain for the next 50 years. Orton (I930) recorded Folliculina ampulla from Plymouth, Fowell (1944) F. viridis from Swansea, and Bruce (I935) $F$. ampulla and $F$. elegans from the Isle of Man. The only recent additions to our knowledge of British Folliculinidae are two notes in Nature by Das (I947a) and by Fowell (I947), and a paper on the biology of some folliculinids by Das ( $1947 b$ ) in which a tentative key of the British species is added at the end. Only six British species are listed in the last-mentioned paper, whereas sixteen species are known from the continent (Fauré-Fremiet, I936 b) and ten from U.S.A. (Andrews, I944). Besides the six species already recorded (Folliculinopsis producta, F. ampulla, Folliculina simplex, F. elegans, F. viridis, and Parafolliculina hirundo), two further species, Folliculinopsis elongata n.sp. and $F$. andrewsi, can now be added to the list of British species.

\section{DESCRIPTIONS OF SPECIES}

\section{Genus FOLLICULINOPSIS Fauré-Fremiet, I936}

The genus Folliculinopsis was erected by Fauré-Fremiet (1936b) to include those folliculinids which have a multiple macronucleus (i.e. like a string of beads). Before this genus was constituted the different species of Folliculina were distinguished with difficulty, as forms with simple and with multiple macronucleus were both included in the same species. Then, again, the delineation of species according to shape, size and colour of the case and of the body led to confusion amongst different workers. Individuals of the same protozoan species do not vary with regard to the simple or multiple character of the nucleus, but Kahl (I932) lists multinucleate forms under three separate genera-Folliculina, Pebrilla and Mirofolliculina-while, on the other hand, 
both uni- and multinucleate forms are lumped together in Folliculina ampulla. I consider the erection of the genus Folliculinopsis as an important step forward in the classification of Folliculinidae.

\section{Folliculinopsis producta (Wright) (Fig. IA)}

Folliculina producta Wright, I858

Folliculinopsis producta Fauré-Fremiet, 1936b

\section{DiAgNOSIS}

Size and case: large size, total length of extended animal I000-I500 $\mu$; tube of case $500-600 \mu$ long, not more than three times the length of the ampulla and having about eight to fourteen spiral thickenings on its wall. Nucleus multiple; consisting of a string of about fourteen beads, extending from near the cytopharynx to the junction of the body with the peduncle in the retracted condition of animal. Cell-body with peduncle long and narrow, tapering gradually up to its attachment on the ampulla; cell-body broadening in the proximal half and remaining of the same width up to base of peristomial lobes. Pigment: colour of animal deep greenish blue (inky, blue predominating); pigment as granules arranged in definite rows throughout body, alternating with the ciliary bands. Ciliary bands: about fifty on body, eight on peduncle, and six on each peristomial lobe. Peristomial lobes are slender attenuated ribbons, tapering at the free end but without a sharp point; $V$-shaped process at junction of lobes; each lobe is about half as long as the tube. Larva elongated and vermiform; posterior extremity rounded; size $200 \times 75 \mu$; dark blue colour concentrated at oral extremity.

\section{LOCALITY}

Plymouth (first record); Cullercoats (Das, I947 $b$ ); attached to Algae and dead Pecten shells from sublittoral region.

\section{REMARKS}

See remarks on the next species.

Folliculinopsis elongata n.sp. (Fig. IB)

Foliculina producta Wright, 1858, in part

Folliculinopsis producta Wright var. elongata Das, I947b

\section{DIAGNOSIS}

Size and case: gigantic size, length $2000-3000 \mu$ when fully extended; shape of case resembles a hockey-stick; tube I000-I5000 $\mu$ long and not less than four times the length of the ampulla; eighteen to thirty spiral thickenings on wall of tube. Nucleus multiple; consisting of a string of about sixteen to twenty beads. Cell-body attached to ampulla by a distinct narrow peduncle which extends beyond the ampulla in the relaxed condition; body fairly broad at free end. Pigment: colour of animal deep bluish green (green predomi- 
nating); pigment granules arranged uniformly in rows alternating with ciliary bands throughout body. Ciliary bands: about fifty on body, eight on peduncle and six or less on peristomial lobes. Peristomial lobes are slender attenuated

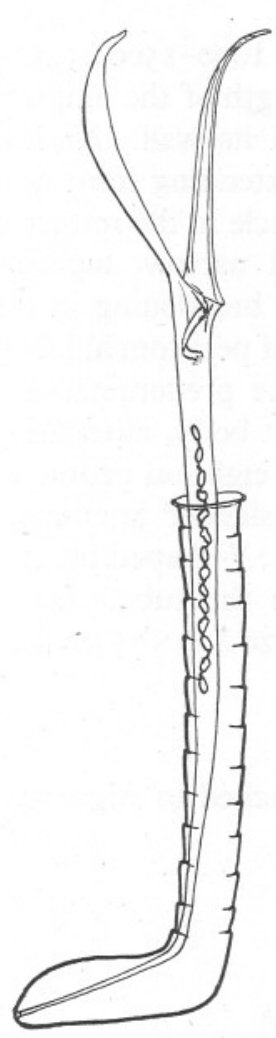

A

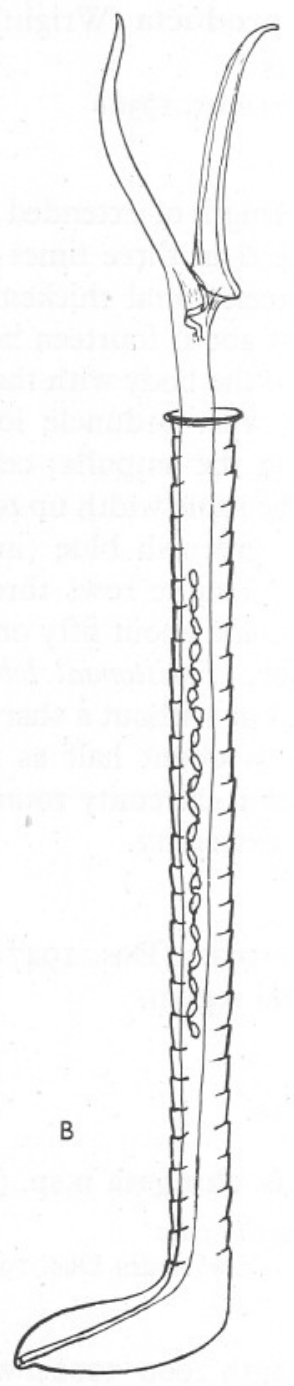

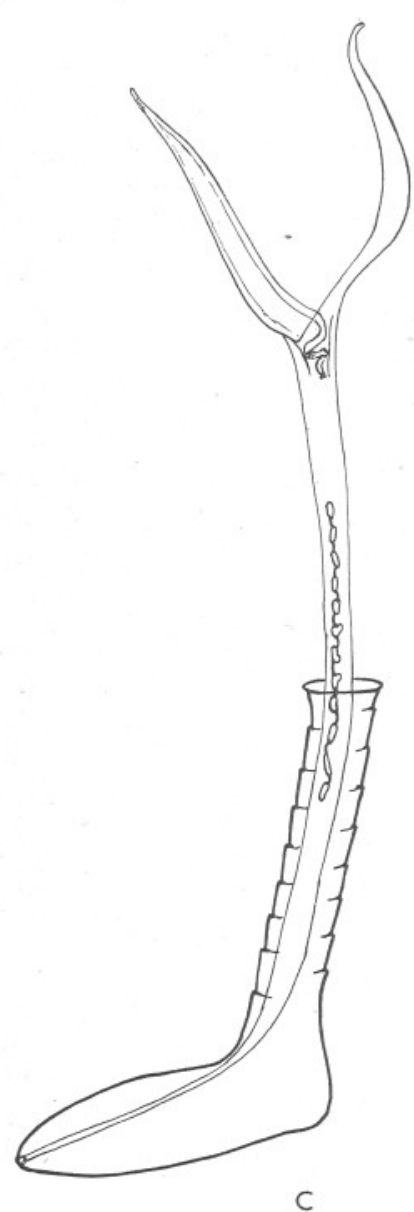

C

Fig. I. A, Folliculinopsis producta (Wright), $\times$ Io0. B, F. elongata n.sp., $\times 70$. C, $F$. andrewsi $(\operatorname{Had} z \bar{i}), \times 150$.

ribbons, tapering but without a sharp point at tip; $\mathrm{V}$-shaped process at junction of the two lobes much exaggerated; each lobe is less than one-third the length of the tube. Larva pear-shaped with posterior end bluntly pointed; size $300 \times$ I $50 \mu$; dark opaque green colour at oral extremity; secretion of case 
by attached, elongated larva with three regions-a head, a neck, and an elongated body; the spiral thickenings of the tube are formed by a special spiral band of cilia on the neck of the larva.

\section{LOCALITY}

Cullercoats (Das, $1947 b$ ); attached to tests of Ciona intestinalis and to various algae.

\section{REMARKS}

The present species was described by me (I947b) as Folliculinopsis producta Wright var. elongata. Since then I have had the opportunity of examining large numbers of specimens resembling $F$. producta, both at Cullercoats and at Plymouth. I can now definitely state that the differences tabulated by me (I 947 b , p. 443) are of a constant character. For example, I examined over a hundred specimens of $F$. producta at Plymouth, and not one of them showed more than fourteen or less than eight spiral thickenings of the case, while almost all the Cullercoats specimens had eighteen to thirty spiral thickenings, the average number being twenty-four. The $F$. elongata forms have been found only at Cullercoats, and I believe this to be a definitely northern species. The differences between $F$. producta and the new species $F$. elongata are even more marked than those between $F$. producta and $F$. andrewsi, the species described next, which has only five to eight turns of the spiral. It may be pointed out here that the gigantic $F$. elongata has not been reported by Andrews (I942, I944) from U.S.A., and that some of the sketches of Kent (I882) which resemble this species, are superimposed tubes of two successive larvae and not one individual lorica. Both producta and elongata are multinucleate and thus they must be placed in the genus Folliculinopsis.

\section{Folliculinopsis andrewsi (Hadži) (Fig. IC)}

Folliculina producta Wright, 1858 , in part

$F$. producta Andrews, I923

Metafolliculina andrewsi Hadži, I938

Folliculinopsis producta Andrews, I942

\section{Diagnosis}

Size and case: fully extended animal 600-1000 $\mu$ long; case shaped like a sock; tube a little longer than ampulla and having five to eight spiral thickenings on its walls. Nucleus multiple; string of about twelve beads. Cell-body with peduncle long, narrow and tapering proximally, body ribbon-shaped when extended and about double the length of the tube. Pigment: greenish blue colour (much lighter than in $F$. producta): pigment granules uniformly distributed in rows. Ciliary bands: peduncle with nine to ten, body with IOO, and peristomial lobes with seven to eight bands. Peristomial lobes are elongated, ribbon-shaped, tapering distally into a pointed but not sharp tip; 
each lobe is only a little shorter than the tube. Larva elongated, vermiform, size $200 \times 50 \mu$; posterior end rounded; bluish pigment concentrated at anterior end.

\section{LOCALITY}

Plymouth and Cullercoats (first record for Great Britain); attached to dead Pecten shells from 3 fathoms, and on test of Ascidiella aspersa.

\section{REMARKS}

The Folliculina described by Andrews (1923, I942) was referred to Hadži (1938), who described it as a species distinct from Folliculinopsis producta Wright, and named it Metafolliculina andrewsi. As this species is multinucleate the name Metafolliculina should give place to Folliculinopsis. I have compared the specimens from Plymouth and Cullercoats, with those described by Andrews and Hadži and have no hesitation in placing them in this species.

If we take the test or case alone into consideration, the present three species of Folliculinopsis appear to form a progressive evolutionary series. $F$. andrewsi is the simplest with only five to eight spiral turns on the tube; $F$. producta comes next with its eight to fourteen spirals; and finally the $F$. elongata tube is not only enormous in length, but has eighteen to thirty spiral turns on its walls. Similarly, the number of beads in the nucleus also shows progressive increase.

\section{Folliculinopsis ampulla (Müller) (Fig. 2)}

Folliculina ampulla Müller, I854, in part

Folliculinopsis ampulla Fauré-Fremiet, $1936 b$

\section{Diagnosis}

Size and case: length of extended animal about $600 \mu$; case $300-500 \mu$ long and usually ridged at its mouth; ampulla flask-shaped, swollen, and large; tube plain and much shorter than ampulla. Nucleus multiple; string of twelve to fourteen beads. Cell-body with peduncle short and thin, body proper stout in middle and narrowed proximally as well as distally. Pigment: blue-green in colour. Ciliary bands not known. Peristomial lobes of two equal lobes, each leaf-like with short pointed tips. Larva: characters unverified.

\section{LOCALITY}

Plymouth (Orton, I930); Port Erin (Bruce, I935); Cullercoats (Bull, unpublished record, Dove Marine Laboratory); attached to submerged plates and tests of Ascidiella aspersa.

\section{REMARKS}

There is no gainsaying the fact that many different species of Folliculinidae have been recorded as Folliculina ampulla by past workers. A look at Fig. 2 will show that Laackmann's sketches (I9IO) depict four different species; similarly Stein's figures (I867) of $F$. ampulla show specimens of at least 
two species; finally, Müller's sketches (I854) of his smaller specimens (200 $\mu$ ) of $F$. ampulla really depict the separate species $F$. simplex Dons. I have made a thorough search for $F$. ampulla both at Plymouth and at Cullercoats, but have failed to collect a single specimen of this species. Fauré-Fremiet (I936a) also states that he could not find them on the Breton coast. I have a strong suspicion that the species Folliculinopsis ampulla (multinucleate) is really non-existent. The uninucleate $F$. ampulla of past workers will on examination turn out to be $F$. simplex or $F$. viridis; while the multinucleate forms, named as $F$. ampulla in the past, would probably be $F$. andrewsi, or $F$. producta. However, I leave the abolition of this species to future workers.

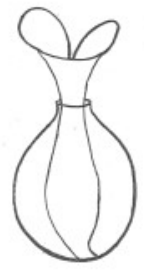

A
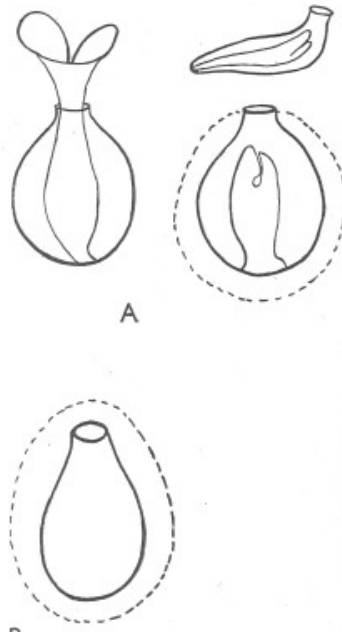

B

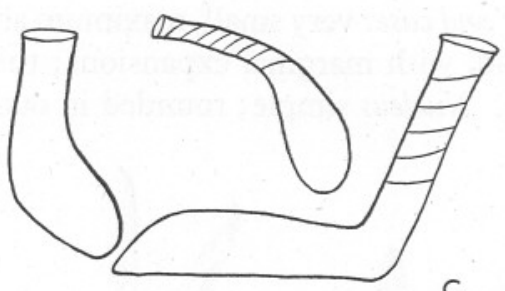

C

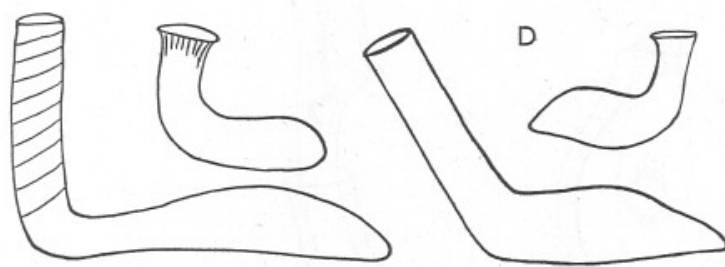

Fig. 2. Folliculina ampulla of various authors, some of which may be true Folliculinopsis ampulla (Müller). A, Folliculina ampulla Müller, the uninucleate small variety, $\times$ I25. B, F. simplex Dons, as sketched by Dons, to show that it is the same species as that sketched and named $F$. ampulla by Müller, $\times 125$. C, F. ampulla: cases as sketched by Stein: there are at least two species represented here, $\times 50$. D, F. ampulla: cases as sketched by Laackmann: all four of them appear to belong to different species, $\times 50$.

\section{Genus FOLLICULINA Lamarck, I8I6}

The genus should now be restricted to those forms that show a simple macronucleus and a single case (not divided by a constriction). The genera listed by Kahl (1932, I933)-Folliculina, Metafolliculina, Mirofolliculina, Parafolliculina, Pseudofolliculina and Pebrilla-were founded by various workers and based mainly on the characters of the case. It has been shown by Fauré-Fremiet (1936b) and Das (I947 b) that the case alone, when considered as a generic or even a specific character, causes endless confusion, if it is not taken in conjunction with other anatomical structures. The present genus Folliculina, from which the multinucleate forms have been removed, presents a well-knit group of species, and no useful purpose will be served by splitting 
it up further. All the multinucleate forms can be included in Folliculinopsis, while the species with a 'double' case (divided into chambers), but simple nucleus, may be put in the genus Parafolliculina.

Folliculina simplex Dons (Fig. 3A)

Folliculina ampulla Müller, I854, in part

F. elegans Stein, I867

F. boltoni Kent, 1882

F. lentus Henneguy, I884

F. simplex Dons, I9I2

DIAGNOSIS

Size and case : very small, maximum about $200 \mu$ long; case patulous, rounded or ovoid, with marginal expansions; tube short or absent and without lipped funnel. Nucleus simple; rounded in outline, and situated in the proximal half
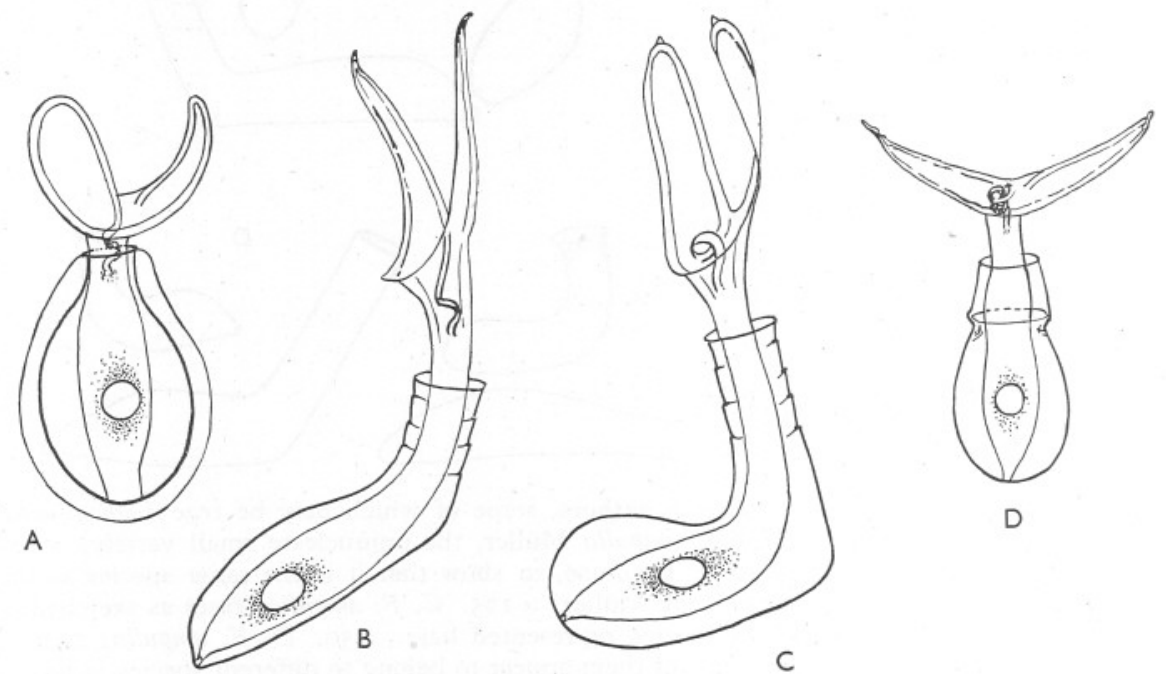

D

Fig. 3. A, Folliculina simplex Dons, $\times 200$. B, F. elegans Clap. \& Lach., $\times$ I 25 . C, $F$. viridis Wright, $\times$ I75. D, Parafolliculina hirundo (Kent), $\times 200$.

of the body. Cell-body with peduncle absent; body short and cylindrical; attached by a broad base to the case. Pigment: body light bluish green generally and bottle-green only about the nucleus. Ciliary bands: about twenty-four on body and five on the peristomial lobes. Peristomial lobes: short and broad, the two appearing as one bilobed structure; left lobe larger and rounded and right one smaller and narrow throughout. Larva cylindrical and elongated, I $50 \times 25 \mu$; narrowed and truncated anteriorly. 


\section{LOCALITY}

Cullercoats (Das, I947a, b); attached to tests of Ciona intestinalis and to submerged plates in aquarium.

\section{REMARKS}

On comparing the figures and descriptions of Müller (I854), Stein (I867), Kent (I882), and Henneguy (I884), it appears that Folliculina elegans, $F$. boltoni, and $F$. lentus, are all one and the same species, and that they are identical with $F$. simplex Dons, I9I2. As $F$. simplex is the first welldefined species, the later name by Dons is retained.

Folliculina elegans Clap. \& Lach. (Fig. 3B)

Folliculina elegans Clap. \& Lach., I858

F. ampulla Laackmann, 1910, in part

\section{DiAgNOSIS}

Size and case: fairly large, extended animal about $600 \mu$ long; case about $450 \mu$; ampulla $250 \mu$; tube shorter than ampulla (I50-200 $\mu$ ) and with three turns of the spiral thickening; ampulla lies horizontally on substratum and the tube placed at an angle of about $45^{\circ}$ (never $90^{\circ}$ ); funnel with expanded collar. Nucleus simple; ovoid or oblong, situated at basal end of body. Cell-body with short thin peduncle; proximal half of extended animal stouter than distal half. Pigment: body of light green colour generally; green pigment concentrated around nucleus. Ciliary bands: about forty on the body and five to six on the peristomial lobes. Peristomial lobes: flat, ribbon-shaped, tapering distally into a sharp tip. Larva: elongated, vermiform; $300 \times 50 \mu$; oral ciliary disk broad and well-marked; after attachment the larva puts forth a long proboscis-like projection, which helps in making the tube of the case.

\section{LOCALITY}

Port Erin (Bruce, I935); Plymouth (first record); Cullercoats (first record); attached to green algae and Flustra.

\section{REMARKS}

One must be very careful in distinguishing the three species: Folliculina elegans Clap. \& Lach., F. viridis Wright, and F. aculeata Clap. \& Lach. All three are uninucleate species, all of them have a comparatively short tube which is never longer than the ampulla, and all have only three spiral turns of the thickening on the tube. Looking at the case, the ampulla of $F$. viridis is the stoutest, although this is the smallest of the three species, and the tube is always shorter in length than the ampulla. The ampulla of $F$. elegans is probably the longest with the tube again shorter than ampulla; while the case of $F$. aculeata is characterized by the ampulla and tube being of about the same length. The peristomial lobes are, however, the main differentiating structures. 
In $F$. viridis each lobe is leaf-like, non-acuminate and ends abruptly in a short, sharp tip; in F. elegans each lobe is ribbon-shaped, tapering, and ends in a somewhat elongated point; while in $F$. aculeata each lobe is acuminate and ends in an accentuated pointed tip. The three species thus form a progressive evolutionary series, so far as the peristomial lobes are concerned. The colour may be distinctive, but I have always found it difficult to distinguish them merely by colour, as variations are quite common in all three species.

\section{Folliculina viridis Wright (Fig. 3C)}

Folliculina ampulla Müller, 1854, in part

$F$. viridis Wright, 1862

F. ampulla Laackmann, I9Io, in part (one of his sketches)

\section{DiAgNosis}

Size and case: smaller than F. elegans, not more than $400 \mu$ when extended; case only $250 \mu$ in length; tube a little more than half the length of the stout quadrangular ampulla, and usually at right angles to it. Nucleus simple; large, ovoid, and situated at about middle of ampulla. Cell-body stout in the middle and tapering at both ends; peduncle short and narrow. Pigment: yellow-green colour (yellow predominating); pigment more concentrated around nucleus. Ciliary bands: about fifty on the body, and five to six on the peristomial lobes. Peristomial lobes flat, leaf-like, with tips rounded; each lobe terminates abruptly in a sharp point of ectoplasm. Larva elongated, vermiform, about $200 \times 40 \mu$; colour yellowish with yellow-green pigment concentrated near the oral ciliary disk; as in F. elegans the larva after attachment puts forth a long proboscislike projection.

\section{LOCALITY}

Swansea (Fowell, I944); Plymouth (first record); Cullercoats (first record). Attached to various green algae.

\section{REMARKS}

$F$. viridis can be easily confused with $F$. elegans; but, as mentioned by Das $(1947 b)$, the smaller size, yellow-green colour, erect tube, quadrangular ampulla, and non-acuminate peristomial lobes, should suffice to distinguish it from $F$. elegans.

Genus PARAFOLLICULINA Dons, I9I4

Parafolliculina hirundo (Kent) (Fig. 3D)

Folliculina hirundo Kent, I882

\section{DIAGNOSIS}

Size and case: very small size, about $180 \mu$ when extended; case horizontal and $\mathrm{I} 30 \mu$ long; annular constriction at base of free end of the case (i.e. a short chamber, the neck, is present). Nucleus simple; ovoidal, situated at about the 
middle of the cell-body. Cell-body short and cylindrical; peduncle absent, attachment by a broad base. Pigment: very feebly coloured; bluish green; colour somewhat dark around nucleus. Ciliary bands: about twenty on the body and five on the peristomial lobes. Peristomial lobes narrow, tapering, nearly symmetrical and lying far apart, so as to create the impression of a single flat $\mathrm{T}$-shaped structure. Larva: resembles that of $F$. simplex, except that it is broadly rounded anteriorly.

\section{LOCALITY}

Channel Islands (Kent, I882).

\section{REMARKS}

I have not been able to find specimens of this species either at Plymouth or at Cullercoats. It is common on the Breton coast of France and should occur on the south coast of England. The distinctive collar-like band at the free end of the case, and the symmetrical peristomial lobes should immediately distinguish it from the similar $F$. simplex.

\section{Key to BRItish Folliculinidae}

\section{(After Das, I947b)}

Macronucleus consisting of a string of beads

Tube not longer than ampulla Tube longer than ampulla and spirally ridged

Tube with five to eight spirals; maximum size of animal I000 $\mu$; peristomial lobes a little shorter than tube.

Tube with eight to fourteen spirals; maximum size $1500 \mu$; peristomial lobes about half as long as tube.

F. producta (Wright)

Tube with eighteen to thirty spirals; maximum size up to $3000 \mu$; peristomial lobes less than one-third the tube.

F. elongata n.sp.

\section{Macronucleus simple}

Case divided by annular constriction

Case entire, not constricted

Parafolliculina hirundo (Kent)

Tube absent; maximum size $200 \mu$; peristomial lobes asymmetrical, short and broad. Folliculina simplex Dons

Tube shorter than ampulla, with three spirals, and at $135^{\circ}$ to ampulla; maximum size $600 \mu$; peristomial lobes tapering. F. elegans Clap. \& Lach. Tube shorter than ampulla, but at $90^{\circ}$ to it; maximum size $400 \mu$; peristomial lobes rounded at tip. 


\section{ACKNOWLEDGEMENTS}

I am greatly indebted to Prof. A. D. Hobson, F.R.S.E., Director, Dove Marine Laboratory, Cullercoats, for giving me facilities for work in the laboratory during 1946-47 and for constant help and criticism. To Mr F. S. Russell, F.R.S., Director, Plymouth Laboratory, I am sincerely grateful for allowing me a table at the Laboratory and access to the library.

\section{SUMMARY}

A brief résumé is given of the work done on British Folliculinidae up to the present time.

Descriptions follow of eight British species, many of which are revised accounts based on personal observations.

A new species, Folliculinopsis elongata, is described.

A revised key for the identification of British Folliculinidae is given.

\section{LITERATURE}

Andrews, E. A., I9I4. The bottle-animalcule Folliculina: ecological notes. Biol. Bull. Woods Hole, Vol. 26, pp. 262-85.

- I923. Folliculina: case making, anatomy and transformation. Fourn. Morph., Vol. 38, pp. 207-78.

- I942. Parafolliculina violacea (Giard) at Woods Hole. Biol. Bull. Woods Hole, Vol. 83 , pp. 9I-6.

— I944. Folliculinids on oyster shells. Fourn. Mar. Res., Vol. 5, pp. 169-77.

- I946. Ingestion organs in folliculinids and in stentors. Fourn. Morph., Vol. 79, pp. 4I9-44.

— I 1947 . Temperature effect upon rate of feeding in a folliculinid. Physiol. Zoöl., Vol. 20, pp. I-4.

Bruce, J. R., I935. Faunistic notes and records. Rep. Mar. Biol. Sta. Port Erin, Vol. 48, pp. 26-8.

BüTSCHLI, O., I887-9. Infusoria in Bronn's Klassen, und Ordnungen des Thier-reichs, Bd. I, Abt. III, pp. 1098-2035.

Claparède, E. \& Lachmann, J., I858. Études sur les infusoires et les rhizopodes, Pts. I and 2. 482 pp. Geneva.

DAS, S. M., I947a. British Folliculinidae (Ciliata, Heterotricha). Nature, Vol. I59, p. 502 .

- $1947 b$. The biology of two species of Folliculinidae (Ciliata, Heterotricha) found at Cullercoats, with a note on the British species of the family. Proc. Zool. Soc., Vol. II7, pp. 44I-56.

Dewey, V. C., I939. Test secretion in two species of Folliculina. Biol. Bull. Woods Hole, Vol. 77 , pp. 448-55.

Dons, C., I9I2. Folliculina-Studien I-III. Arch. Protistenk., Bd. 27, pp. 73-93.

- I9r4. Folliculina-Studien IV. Vorläufige Bermerkungen über die Systematik der Folliculiniden nebst Beschreibung neuer norwegischen Arten. Tromsø Mus. Aarsh., Vols. 35-6, pp. 59-92. 
FAURÉ-Fremiet, E., 1932. Division et morphogenèse chez Folliculina ampulla O. F. Müller. Bull. Biol. Fr. 'E Belg., T. 66, pp. 77-I Io.

- $1936 \mathrm{a}$. The Folliculinidae (Infusoria, Heterotricha) of the Breton coast. Biol. Bull. Woods Hole, Vol. 70, pp. 353-6o.

— 1936b. La famille des Folliculinidae (Infusoria, Heterotricha). Mém. Mus. R. Hist. Nat. Belg., Ser. 2, Fasc. 3, pp. II 29-75.

Fowell, R. R., I944. The ecology of a rock pool. Proc. Swansea Sci. Field Nat. Soc., Vol. 2, pp. I92-2I2.

_ 1947. British Folliculinidae (Ciliata, Heterotricha). Nature, Vol. I60, p. 28.

Giard, A., I883. Sur les infusoires de genre Freya. Bull. Sci. Dépt. Nord., Ser. 2, T. I5, pp. 264-5.

HaDžI, J., I937. Ueber die Xenoekie der adriatischen Follikuliniden. C.R. XIIe Cong. Intern. Zool., Lisbonne, Vol. I2, Sect. V, pp. 924-40.

- 1938. Beitrag zur Kenntnis der adriatischen Folliculiniden (Inf. Heterotricha), I. Subfamilie: Eufolliculininae. Acta Adriatica, Vol. 2, pp. I-46.

Henneguy, L. F., I884. Note sur un nouvel infusoire hetérotriche, l'Ascobius lentus. Bull. Soc. Philom. Paris, T. 8, pp. I22-5.

KAHL, A., I932. Urtiere oder Protozoa; I. Wimpertiere oder Ciliata (Infusoria). Die Tierwelt Deutschlands, Teil 25 (3), pp. 399-650. Jena.

- I933. Ciliata libera et ectocommensalia. Die Tierwelt der Nord- und Ostsee. Lief. 23, Teil II, c3, pp. 29-I46. Leipzig.

Kent, W. SAville, I88I-2. A Manual of Infusoria, Vol. 2. London.

LAACKMANN, H., I9IO. Zur Kenntnis der heterotrichen Infusoriengattung Folliculina Lamarck. Deutsche Südpolar-Exped., Bd. xII, Zool. IV, pp. 77-89.

LAMARCK, J. B., I8I6. Histoire naturelle des animaux sans vertèbres (II). Paris.

MöвıUS, K., I887. Das Flaschenthierchen Folliculina ampulla. Abh. Nat. Ver. Hamburg, Bd. I0, pp. I-I4.

MÜlleR, JoH., I854. Ueber verschiedene Formen von Seethieren. Müller's Arch. Anat., I854, pp. 69-98.

ORTON, J. H., I930. Experiments in the sea on the growth-inhibitive and preservative value of poisonous paints and other substances. Fourn. Mar. Biol. Assoc., Vol. I6, pp. $373-452$.

Penard, E., I9I9. On Folliculina boltoni (S. Kent). Fourn. Roy. Micr. Soc., I919, pp. 305-19.

RydER, J. A., I880. On the occurrence of Freia producta Wright in Chesapeake Bay. Amer. Nat., Vol. I4, pp. 810-II.

SAHRHAGE, H., I9I6. Úber die Organisation und den Teilungsvorgang des Flaschentierchens (Folliculina ampulla). Arch. Protistenk., Bd. 37, pp. I39-74.

SteIn, Fr., I867. Der Organismus der Infusionsthiere, Abt. II(I): Darstellung der neuesten Forschungsergebnisse über Bau, Fortpflanzung und Entwicklung der Infusionsthiere. Leipzig. [Allgem. Theil, pp. I-I40.]

Thomsen, R., I921. Einiges über die Morphologie von Folliculina boltoni. Arch. Protistenk., Bd. 44, pp. 83-98.

Wright, T. S., I858-9. Description of new Protozoa. Edin. New Phil. Fourn. (N.S.), Vol. 7, pp. 276-8I; Vol. 10, pp. 97-104.

- 1862. Observations on British Protozoa. Quart. Fourn. Micr. Sci., Vol. 2, pp. 217-2I. 